\title{
LIFE AND DEATH AMONG THE EARLIEST MAYA: A REVIEW OF EARLY AND MIDDLE PRECLASSIC BURIALS FROM THE MAYA WORLD
}

\author{
Gabriel D. Wrobel $\mathbb{B}^{\mathrm{a}}{ }^{\mathrm{a}}$ Raúl Alejandro López Pérez, ${ }^{\mathrm{b}}$ and Claire E. Ebert ${ }^{\mathrm{c}}$ \\ ${ }^{a}$ Department of Anthropology, Michigan State University, 655 Auditorium Dr., East Lansing, Michigan 48824, United States \\ bepartment of Postgraduate Studies, Universidad Autónoma de Yucatán, km 1 Carretera Mérida Tizimín Cholul, Mérida 97305, Mexico \\ 'Department of Anthropology, University of Pittsburgh, 3302 WWPH, Pittsburgh, Pennsylvania 15260, United States
}

\begin{abstract}
This article presents a review of the earliest Maya skeletal remains thus far found, including a list of 398 burials dating to the Early (1800-900 B.C.) and Middle Preclassic periods (900-300 B.C.) and adjacent regions. These sites are spread throughout the Maya region and the data allow basic descriptive syntheses about early mortuary behavior and aspects of health and diet. Poor preservation and differences in scoring and reporting severely limit the scope of interpretation possible at this point, but it is hoped that this review stimulates coordinated research into the biology of early groups.
\end{abstract}

\section{INTRODUCTION}

Despite evidence for continuous human presence in the Maya Lowlands for at least 12,000 years (see Wrobel et al. 2021), most bioarchaeological research in the region is dominated by a focus on the most visible and accessible contexts that date to the Classic period (A.D. 300-900/1000). Most of what we know about the biological variability of ancient populations, therefore, reflects the specific patterns of social, economic, political, and environmental complexity that characterized the large and highly stratified communities of this era. While studies of the Classic Maya provide foundational knowledge about these preindustrial state-level societies, as well as important lessons about the dire biological consequences of stresses placed on populations from environmental instability, political factionalization, and social inequality, equally fascinating is the story of the rise of large and complex Maya societies during the Preclassic (Ebert et al. 2019; Scherer 2017; Somerville et al. 2013; Wright and White 1996). Bioarchaeological studies in other areas of the world that have considered a deeper history have demonstrated that significant biocultural changes occurred as a result of growing social, economic, and technological complexity (e.g., Cohen and Armelagos 1984; Cohen and Crane-Kramer 2007; Larsen et al. 2019; Pihasi and Stock 2011; Redfern 2020). It is widely accepted that a pan-Maya identity had arisen in eastern Mesoamerica by at least 1200/1000 B.C. (if not before), and that by the beginning of the Late Preclassic period, around 300 B.C., intensive agriculture, hierarchical rulership, and complex social and economic institutions were already well-established (Doyle

E-mail correspondence to: wrobelg@msu.edu
2020). Unfortunately, we know very little about how this long process unfolded in the Maya area from a biological perspective.

\section{WHY STUDY EARLY SKELETONS?}

Studies of human skeletons dating to the earliest phases of settled village life provide an essential source of biocultural data to address a broad range of questions posed by archaeologists, including those related to economies and subsistence, changing political and social conditions, and individual health and well-being. These have most often been framed through the lens of cultural evolutionary models, with an eye towards identifying and timing the precursors of the cultural and biological features characteristic of later time periods. In these contexts, bioarchaeological research tends to highlight behavioral correlates with the establishment and development of social, economic, and political complexity in the Maya region as reflected by skeletal remains and mortuary practices. This review identifies and discusses the picture provided by relevant skeletal data reported from the earliest lowland Maya communities. In support of this effort, we have created a table listing 398 individuals from 40 sites that are assigned Early and Middle Preclassic dates (1800-300 B.C.; Figure 1, Supplementary Table 1). These remains were identified through an extensive literature review, consultations with archaeologists focused on Preclassic contexts, and use of a database of Maya burials created and maintained by Vera Tiesler. While this list is not a completely exhaustive dataset, it represents the largest compilation to date of published Early and Middle burial information from the Maya region, broadly construed. The scope of this review is purposely limited to focus on our emerging picture of biology and mortuary behavior in the earliest Maya contexts, primarily in the Southern Lowlands, though we discuss 


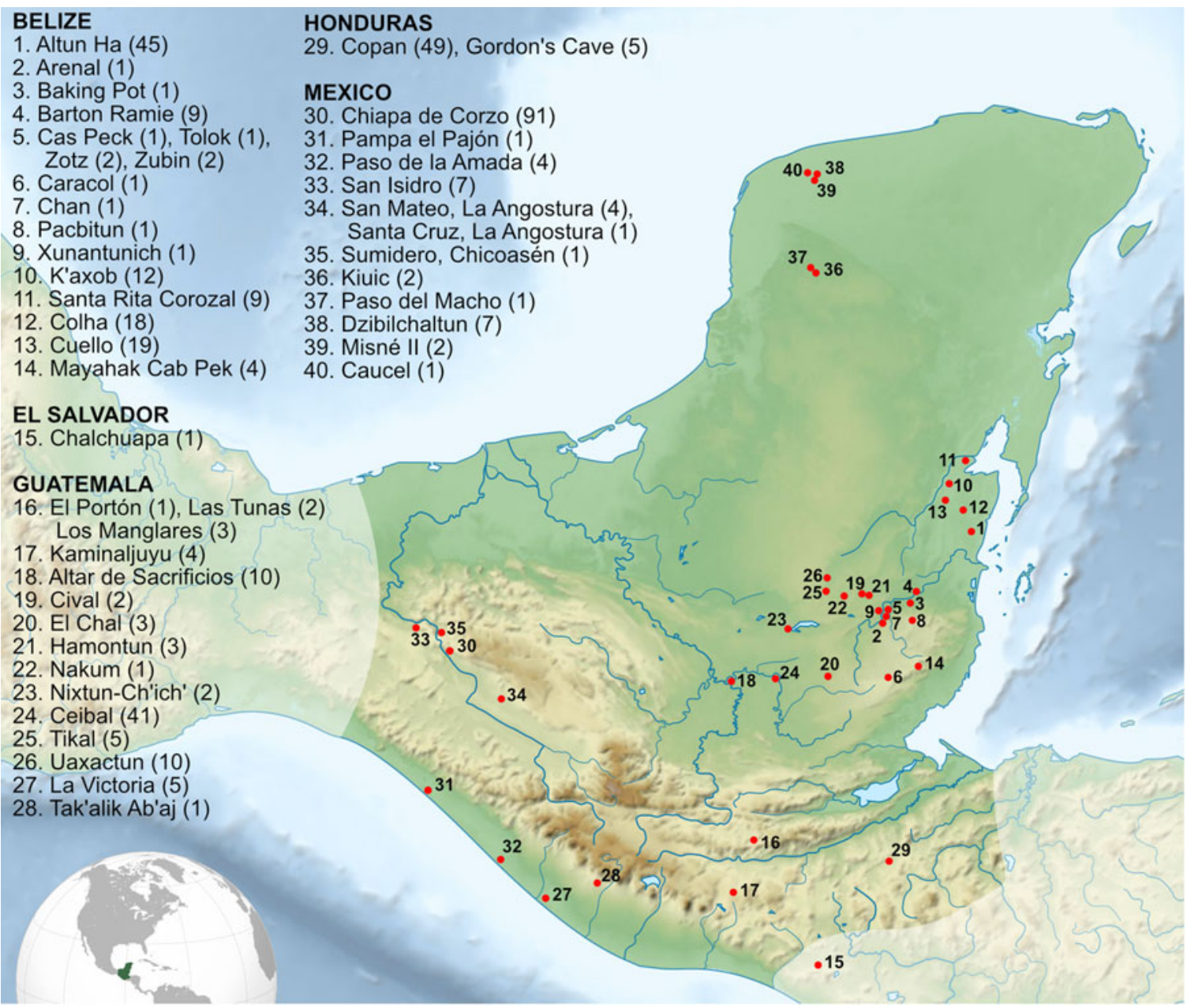

Figure 1. Map of sites in the Maya region with burials dating to the Early and/or Middle Preclassic period. Number of early burials for each site is in parentheses. Map created by Wrobel based on map by Sémhur, https://commons.wikimedia.org/wiki/ File:Maya_civilization_location_map-blank.svg.

relevant trends from adjacent regions when appropriate. For broader reviews of Maya bioarchaeology that include the more extensive mortuary record for the Late Preclassic and subsequent eras, we direct the reader to an excellent recent synthesis by Scherer (2017; see also Spence and White 2009; Wright and White 1996).

Our ability to synthesize the Early and Middle Preclassic mortuary and skeletal data is limited by a number of obstacles to bioarchaeological analyses, stemming from small and biased samples, limited geographic representation, lack of chronological control, and poor preservation, all of which are discussed in more detail at the end of the article. However, despite the frustrating nature of these assorted challenges, an increasing focus by archaeologists on early periods has yielded relevant skeletal data that, with careful consideration of confounding variables, provide us with an emerging picture of biological diversity of these poorly understood periods.

\section{SKELETAL STUDIES OF THE EARLIEST MAYA}

The study of early Maya skeletons has the potential to address several essential questions related to both biological and cultural processes, as well as foundational issues about how these sets of factors are intimately entwined. Thus far, bioarchaeological investigations of early Maya communities have focused on changes in diet and health that relate to increasing reliance on domesticated plants, population density, and trade and exchange, and on diversification of mortuary practices that relate to increasing social complexity and ritual elaboration.

\section{THE MORTUARY RECORD}

Mortuary treatment is the main source of data reported for Early and Middle Preclassic Maya burials. Specifically, there have been a number of studies that have used structured burial data to document changes in mortuary ritual over the course of the Preclassic, interpreting these changes within the context of increasing social complexity and broader integration of the Maya with each other and with other Mesoamerican groups (see recent review by Horn et al. 2020; Ebert and Awe 2021). The Middle Preclassic is often identified as a precursor to the fluorescence of Maya civilization, hallmarks of which are established in the Late Preclassic (see discussion by McAnany 2004:4-5). From a mortuary perspective, this transition is usually demonstrated by highlighting examples of new forms of behavioral complexity, including standardization 
of burial practices between sites and regions, and the appearance of wealthy and/or exotic grave good assemblages, specialized mortuary facilities in both public and residential settings, and a diverse array of funerary and non-funerary body treatments. Beyond the constructed environments of early population centers, skeletons from caves and rock shelters in Honduras (Brady 1995), southern Belize (Hill et al. 2018; Kennett et al. 2020), and the Yucatan (González et al. 2013; Wrobel, Hoggarth, and Marshall 2021, this Special Section) show that use of these mortuary locations, which was widespread in the region by the Late Preclassic and Protoclassic (Garza et al. 2001; Wrobel et al. 2017a, 2017b), are consistent with traditions that have origins at least as far back as the Late Pleistocene. Middle Preclassic mortuary behavior does appear to be generally less complex than that of the Late Preclassic, especially in earlier contexts. As noted in other articles in this Special Section, however, communities established prior to 300 B.C. were highly variable in their sociopolitical and economic systems. Accordingly, the mortuary record also demonstrates intriguing indicators of complexity emerging earlier.

One of the main uses of mortuary data from early contexts has been to complement archaeological studies investigating the origins of the large and elaborate public architecture that dominates Classic-period site cores. These early buildings, which begin to be constructed in earnest during the Middle Preclassic ( 800-700 B.C.), are typically low platforms and often contain cached objects assumed to be ritual paraphernalia (Inomata et al. 2013, 2015; Rice 2015, 2021). Specifically, placement of burials within these non-residential structures is assumed to broadly reflect public social roles within the community (rather than identification with household contexts in which most others are buried). Thus, public burial location is seen as a valuable means of identifying evidence for social differentiation of individuals or groups responsible for their construction and the public activities performed there.

Within settlement centers, the placement of the earliest funerary contexts is often generalized as being largely restricted to residential architecture. Burial under house floors and in nearby structures is a widespread practice that appears to be established early and persists, alongside a diversity of other mortuary practices, throughout the pre-Contact period (Joyce 1999; McAnany 1995). At sites such as Cuello and K'axob in northern Belize, for instance, almost all individuals dating to the Early and Late Middle Preclassic were found in houses or ancillary structures (Hammond 1995:50, 52; Henderson 2003; McAnany et al. 1999:134). While it is true that most burials are found in residential contexts (in the Classic period as well), it seems likely that our picture is restricted by where we dig, and that relatively few individuals were buried in association with architecture. Even at sites like Cuello and K'axob, where burials are found in residential buildings, it should be noted that these make up only a tiny fraction of the total population, suggesting that most community members were buried elsewhere; thus, while some rituals were focused on social reproduction of household groups, residential burial was only a small part of the mortuary program. There also appear to be many exceptions to residential placement, even among the earliest burials, suggesting that mortuary practices among early Maya communities were already quite diverse, likely reflecting social identities beyond associations with specific households or local corporate groups (Joyce 1999; McAnany and López 1999; McAnany et al. 1999). For instance, no burials were found within residential structures in the earliest habitation phases at Chiapa de Corzo (prior to 550 B.C.) or Ceibal (prior to 770 B.C.), indicating the presence of some other, as yet unidentified non-residential interment areas (Lowe 1964; Palomo et al. 2017:310). At Ceibal (formerly Seibal), very few burials were found in residential contexts until the Late Preclassic, prior to which they instead appear in public ceremonial complexes and large platforms. Other sites also demonstrate early mortuary use of public architecture, including round structures at Altun Ha (Pendergast 1982:Figure 98) and Cahal Pech (Aimers et al. 2000; Ebert et al. 2019), an E-Group at Ceibal (Palomo et al. 2017:310), and platforms at Cuello (Hammond et al. 1991, 1992), Santa Rita Corozal (Chase and Chase 2006:89; Chase et al. 2018:160), and Ceibal (Palomo et al. 2017:310-311).

Mortuary patterning and analyses of grave furnishings have been useful in exploring status differentiation and the development of social hierarchy within early communities, and the presence of exotic items within graves may indicate that the source of wealth is tied to trade with other regions. Overall, the earliest burials include few, if any, grave goods, and when present they tend to be relatively simple and sourced locally (Hammond et al. 1992: 963, 1995:127; McAnany et al. 1999:134). These items include personal adornments, such as earrings, necklaces, pectorals, and wristbands, as well as ceramic vessels and figurines, animal bones, and stone artifacts. While most (but not all) Middle Preclassic graves are furnished modestly or not at all, over time the presence of grave goods and examples of ostentation become more common, though the extent of this varies greatly between communities.

At Altun Ha, the earliest burials, dated sometime before 600 B.C., were found in Structure C-13 and mostly have few or no associated artifacts. Pendergast (1982:200) notes a hiatus in mortuary use of the building, after which it was refurbished into a round structure that was used intensively for burial. This later phase of use likely dates to 500-400 B.C. and several of the associated burials have rich furnishings, including trade items like jadeite, spondylus, and obsidian. Similarly, at Cuello, grave goods were common by the end of the Early Preclassic, and by the Bladen phase (900-600 B.C.) of the Middle Preclassic were also included with children, suggesting the establishment of affiliative status (Hammond et al. 1991:362, 1992:961). The appearance of long-distance trade items (jade and greenstone) in the burial assemblage by $\sim 700$ B.C. coincides with other indicators of social complexity at the site (Hammond 1995: 50). Burials at Ceibal dating to the eighth century B.C. include elaborate grave wealth (Palomo et al. 2017:310-311), and at the Puuc site of Paso del Macho, an Early Middle Preclassic adolescent male was buried with numerous ceramic vessels in the center of a plaza and in close association with several jade caches (Parker et al. 2020). Finally, there are a number of examples of particularly wealthy graves, likely indicative of the individuals' leadership roles. In particular, Cuello's B160, dated to $~ 500$ B.C., includes ceramics, jade and shell beads, carved bone tubes, and a gorget with a mask design (Hammond et al. 1992:961-963). At Santa Rita Corozal, Burial SD P24A-1 contained three pottery vessels and four small tubular jadeite beads (Chase and Chase 2006:93). At K'axob, Burial 43 was interred with more than 2,000 small, marine-shell beads (arranged as bracelets and upper arm bands) and two ceramic vessels (McAnany and López 1999:155). By the Late Preclassic, there appears to be a shift in elaborate burial activity from domestic contexts to public/communal ones (Hammond 1995:57).

Changes in early mortuary ritual within some communities include increased standardization of mortuary treatment, which may indicate more rigid and defined social messaging, perhaps related to group identity. For instance, at Santa Rita Corozal, 
Middle Preclassic burials often contain a single small vessel placed upright near or on the chest (Chase et al. 2018:160). At Cuello, the earliest burials are diverse, while later burials in more formal Middle Preclassic buildings have more uniform grave goods and are treated more consistently, such as having vessels covering their skulls and standardized body positioning (Hammond 1995:50; Hammond et al. 1991:Figure 5, 1992).

Body treatment can also reflect aspects about social organization at the level of the community and broader region. The vast majority of burials from the Early and Middle Preclassic are primary interments in simple pits, with no evidence of intensive or extended mortuary ritual (McAnany et al. 1999:134). The most elaborate funeral architecture consists of cists in which slab stones surround the body (Hammond et al. 1991:Figure 5, 1992). Many of the more complex mortuary practices that are ubiquitous in the Late Preclassic, such as secondary and multiple burials, appear to be almost completely absent in the Middle Preclassic. However, there are notable exceptions that demonstrate the presence of mortuary complexity beginning in some communities much earlier than 300 B.C. For instance, at Santa Rita Corozal, Chase and colleagues (2018:164) note a link in the Middle Preclassic between fire pits and interments, which is perhaps a precursor to ritual burning commonly found at many sites throughout the Classic period. The burials from Altun Ha's Structure C-13, dating to the later Middle Preclassic, include secondary interment (Pendergast 1982:178) of five individuals placed atop two primary individuals (Burial C-13/5 [RP-610]). This structure also contained a large number of caches, some with human bones, perhaps indicating more elaborate and extended mortuary practices. Similarly, Cuello and K'axob each have secondary burials dating to the Early Middle Preclassic (Robin and Hammond 1991:208; Storey 2004). Several burnt long bone fragments were found at Cahal Pech dating to the Terminal Early Preclassic (Cunil phase), and Awe (1992:335) suggests that these likely reflect ritual practices. As early as 775-700 B.C., Ceibal's burials include examples of multiple and secondary burial, and burials found in public areas, including infants (Palomo et al. 2017:310-311). Cut marks are visible on the chin of Middle Preclassic Burial 9 at Cuello, which was also the only Middle Preclassic individual at the site buried in a seated position (Saul and Saul 1991:155; Hammond 1995:50). Perhaps most dramatic is the evidence of postmortem modification of a cranium from Cuello. The frontal had holes drilled in it to allow suspension, perhaps as a personal adornment, and was found in what may be a feasting deposit. Hammond and colleagues (2002:952) interpret this object as likely relating to ancestor veneration, and note the presence of a separate Preclassic primary inhumation whose skull had been removed secondarily.

Studies of ancient social systems have utilized demographic data to test whether specialized social or economic roles were assigned based on age and/or sex. This practice could be indicated by differential access to specific mortuary locations or mortuary treatments. While poor preservation limits the reliability of sex and age estimation, and therefore the scope of interpretations, what is clear is that these early Maya burial contexts are not true cemeteries, and instead comprise groups of individuals selected for some reason as yet unclear. For example, Middle Preclassic skeletal assemblages are dominated by males and by adults, suggesting that the skeletal series are not representative of the general population (Saul and Saul 1997; Thompson 2005). Out of the 130 sexed individuals in Supplementary Table 1,84 were male or likely male, while only 46 were female or likely female. Of the rest, 90 were not sexed because they were infants or juveniles, while the remaining 179 were adolescents or adults with no sex estimate reported. The presence of adults of both sexes as well as children in most contexts suggests that selection criteria were likely based primarily on family or corporate group membership, rather than on other specific achieved social roles. These roles may instead be reflected in other variations in burial treatment or furnishings. It is certainly likely that taphonomy partially accounts for subadults and females being underrepresented (Gordon and Buikstra 1981), but this pattern is consistent with some (Hernández Espinoza and Márquez Morfín 2015; Wright 2006), but not all (Wrobel et al. 2017b:312) later mortuary contexts from both public and residential contexts in which preservation is better, suggesting that cultural practices are also at work in at least some instances. Among the earliest burials at Cuello, for example, Hammond (1995:50) notes no correlations between age and sex categories and access to multiple grave goods or long-distance trade items. Thus, while the small groups of burials do not provide data useful in paleodemographic reconstructions, these data instead provide a perspective on social organization through the lens of differential access to mortuary locations.

In sum, it does appear that mortuary complexity increases over time at sites, and that this is related to broader social changes within these communities. However, it is also clear that there is a lot of variation in mortuary behavior between communities and that aspects of the more standardized forms of mortuary complexity characterizing the Late Preclassic have their roots in the Middle Preclassic, appearing in different ways and at different times. It stands to reason, then, that many of the aspects of mortuary complexity that are well-documented for the Late Preclassic have their origins in the Middle Preclassic. In part, this issue of timing is clouded by confusion about the ceramic sequence. Chase and Chase (2006:96) note that ceramic complexes usually considered to be sequential in fact co-occur in stratigraphic levels and even within individual graves, suggesting that there is temporal overlap between them. Furthermore, it is worth noting that the dating and ceramic forms for the Middle Preclassic are not uniform throughout the Maya area, and the 300 B.C. date that typically marks the break between the Middle and Late Preclassic ceramic forms is simply a convention that was established at Uaxactun (Arlen Chase, personal communication 2020). Thus, the complicated nature of the mortuary record undoubtedly demonstrates that the transition to complexity does not occur everywhere at the same time. This should come as no major surprise, as many of the more complex mortuary practices occur first in larger communities, such as Ceibal and Altun Ha.

\section{MOBILITY}

While mobility studies using strontium, oxygen, and, more recently, sulfur and lead isotopes, have seen an explosion in the recent Maya bioarchaeology literature (e.g., Ebert et al. 2021; Freiwald 2020; Price et al. 2010, 2015; Sharpe et al. 2016), there has been a clear dearth of analyses focused on the earliest skeletal remains from the region, inhibiting our ability to make any type of definitive statement about movement and migration during the Early and Middle Preclassic. Available strontium $\left({ }^{87} \mathrm{Sr} /{ }^{86} \mathrm{Sr}\right)$ data, which can reflect migration from isotopically distinct regions when ${ }^{87} \mathrm{Sr} /{ }^{86} \mathrm{Sr}$ values in tooth enamel differ from the geologic ${ }^{87} \mathrm{Sr} /{ }^{86} \mathrm{Sr}$ values of the burial location (Price et al. 2002), primarily come from a recent study by Palomo (2020) at Ceibal. Values for ${ }^{87} \mathrm{Sr} /{ }^{86} \mathrm{Sr}$, combined with lead and oxygen from enamel, show that at least one individual 
(Burial 132C) from the Early Middle Preclassic Real 3 phase (1000-700 B.C.) was non-local to Ceibal, possibly migrating from the Usumacinta or Peten regions of Guatemala (Palomo 2020: 183). The ${ }^{87} \mathrm{Sr} /{ }^{86} \mathrm{Sr}$ data from individuals dating to the Late Middle Preclassic Escoba (1/2) phase (700-300 B.C.), show that all individuals were local to the Ceibal region, despite many burials representing children found in a sacrificial context on the E-Group (Palomo 2020:187). Isotopic studies of mobility using ${ }^{87} \mathrm{Sr} /{ }^{86} \mathrm{Sr}$ analyses are not well-represented from other parts of the Maya region, though available data from the Belize Valley region (see Freiwald 2020) document limited migration during the Middle Preclassic. In another study, Wright and colleagues (2010) used $\delta^{18} \mathrm{O}$ values from tooth enamel for examining movement and migration from the Middle Preclassic through Late Postclassic at the highland site of Kaminaljuyu. The single Middle Preclassic individual in this study had a $\delta^{18} \mathrm{O}$ value that was low, but still consistent with a local origin.

Mobility studies represent an important topic for future research, as much of the interest in early sites is focused on determining the extent of political and economic connections between early population centers within the Lowlands and between other regions (e.g., Gulf Coast Olmec, central Mexico). Additional studies seeking to identify migrants by their non-local isotopic signatures could help to clarify these broader questions, determining whether the presence of exotic trade items at sites was accompanied by the arrival of new groups moving into the area, or whether initiation of large-scale construction at sites resulted from the expansion of populations from established centers or was spurred internally. Studies of later Maya groups have shown that long-distance movement of individuals was quite common throughout the Classic and Postclassic periods (for examples, see Freiwald 2011, 2018, 2020; Hodell et al. 2004; Price et al. 2010, 2015; Trask 2018), and it seems likely that the same would be true for the earliest communities.

\section{DIET AND HEALTH}

In other areas of the Americas (and elsewhere in the world), there has been a major emphasis on documenting the transition to agriculture as it relates to the rise of social complexity. In the Maya Lowlands, and the rest of Mesoamerica, the adoption of domesticates predates the Early Preclassic, but is still relevant for understanding the formation of early Maya culture. Skeletal studies from other world regions have traditionally focused on characterizing health, dietary, and demographic shifts that accompanied changing subsistence patterns by comparing data from hunter-gatherers, horticulturists, and agriculturists (Cohen and Armelagos 1984; Cohen and Crane-Kramer 2007; Larsen et al. 2019). This body of work has documented a variety of complex biocultural effects related to the transition to agriculture, demonstrating how it related to phenomena like population growth and movement, intentional and unintentional changes of local environments, the rise of new infectious and noninfectious diseases, and changes in social organization and complexity. In Mesoamerica, most archaeological studies focused on this transition have come from southwest and central Mexico, where teosinte was first domesticated around 9,000 years ago, as evidenced by changes in corn cobs found in stratified deposits (Blake 2015) and modern genomic studies (Doebly 2004; Kistler et al. 2018). Even in the homeland of maize, however, human skeletal remains dating to this period $(>3,000$ years ago) are quite rare and analysis is further limited by poor preservation and contamination issues (Kennett et al.
2020). In the Maya Lowlands, the presence of maize microfossils, including phytoliths and starch, indicate its dispersal across Mesoamerica by $\sim 5000$ cal B.C., along with other domesticates (e.g., Curcurbita; Piperno 2011). Evidence for maize cultivation in the form of microfossils first appears around ca. 4500 B.C. in northern Belize (Rosenswig et al. 2014), with more intensive agriculture associated with dramatic deforestation and erosion across the Lowlands between 2500 and 1500 cal B.C. (Anselmetti et al. 2007; Pohl et al. 1996). Direct evidence for maize consumption through isotopic paleodietary studies, however, is limited in central Mexico and the Maya Lowlands by the paucity of skeletal remains associated with early agricultural contexts, biasing studies about the rise of agriculture in Mesoamerica to focus on later intensification rather than its initial establishment.

Recent work in the Maya Mountains of southern Belize has provided a rare glimpse of the transition to agriculture from a skeletal perspective (Kennett et al. 2020). An analysis of stable carbon $\left(\delta^{13} \mathrm{C}\right)$ and nitrogen $\left(\delta^{15} \mathrm{~N}\right)$ isotope measurements focuses on 52 radiocarbon-dated individuals interred in two rock shelters over the course of around 10,000 years. When combined, $\delta^{13} \mathrm{C}$ and $\delta^{15} \mathrm{~N}$ isotope measurements on human bone collagen are a wellestablished proxy for the types of dietary proteins consumed by individuals (Ambrose and Krigbaum 2003; DeNiro and Epstein $1978,1981)$. Values for $\delta^{13} \mathrm{C}$ in plants are determined by photosynthetic pathways used by $\mathrm{C} 3$ (Calvin-Benson; trees, shrubs) and $\mathrm{C}_{4}$ (Hatch-Slack; grasses) species (Smith and Epstein 1971; van der Merwe 1982). While most plant foods consumed by the prehistoric Maya were $\mathrm{C} 3$ plants, the most frequently consumed $\mathrm{C} 4$ plant was maize, allowing $\delta^{13} \mathrm{C}$ values to track the increasing dietary importance of maize as a staple crop. Nitrogen isotope $\left(\delta^{15} \mathrm{~N}\right)$ values in human bone vary with trophic level, increasing stepwise by approximately +3 to $+5 \%$ o between trophic levels (Bocherens and Drucker 2003). Because the well-preserved skeletal series from the Maya Mountains rock shelters is the only one in the lowland neotropics that spans the transition to maize-based food production, it provides unique and important information about the nature and timing of agricultural adoption in the region. Based on shifts in $\delta^{13} \mathrm{C}$ values, Kennett and colleagues (2020) found that maize became a significant dietary staple ( $\sim 30$ percent of total diet) starting around 2700-2000 B.C. After this time, maize contributed over 70 percent of the total dietary protein for most individuals, resulting in a dietary significance for maize comparable to Classic-period diets (Kennett et al. 2020).

Dietary and health studies of the Early and Middle Preclassic periods have been mainly descriptive due to small sample sizes and poor preservation of the human skeletal series. We provide a few examples of existing studies characterizing health and dietary indicators among the earliest Maya based on isotopic geochemical analyses and pathological lesions visible on bones and teeth. In general, early data are discussed in the context of agricultural intensification and increasing social differentiation. It should be noted that data from the small numbers of early burials are often grouped together with Late Preclassic datasets. Diachronic dietary developments have therefore been examined by assigning individuals to different periods (Preclassic versus Classic), so that discussion tends to focus on the nature of the Preclassic to Early Classic transition, while nothing can said specifically about Early or Middle Preclassic individuals. These studies generally show a trend of increasing reliance on domesticates from the Preclassic through the Postclassic, though this is not always consistent. Generalized Preclassic data from the Pasión subregion of Guatemala is available 


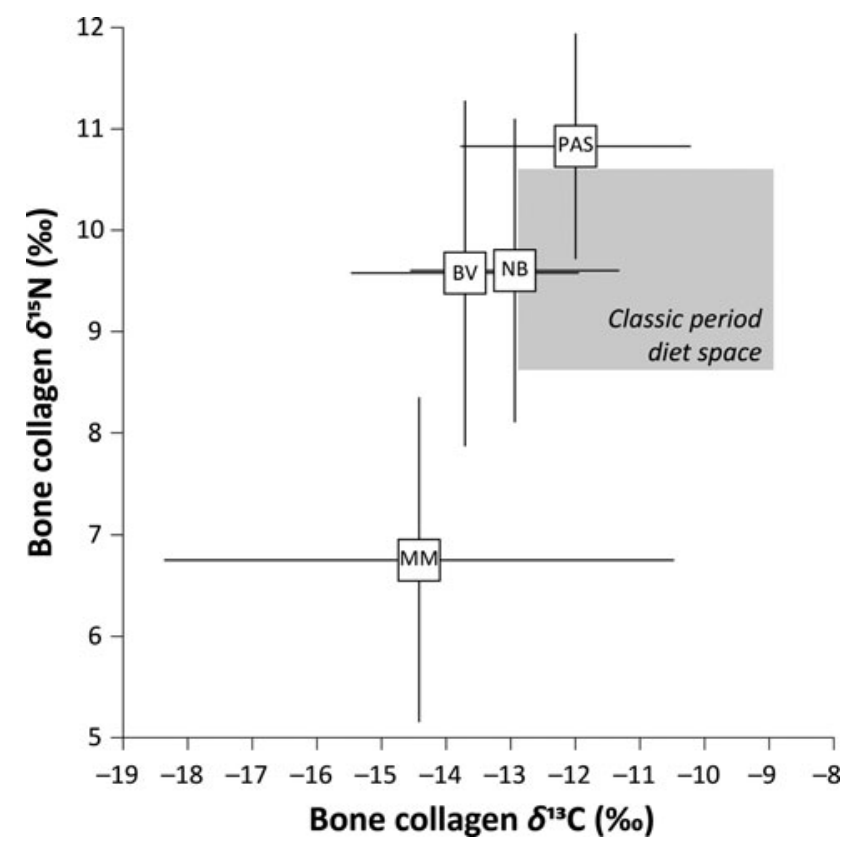

Figure 2. Bivariate plots of mean carbon $\left(\delta^{13} \mathrm{C}\right)$ and nitrogen $\left(\delta^{15} \mathrm{~N}\right)$ isotope values for the Early and Middle Preclassic Maya lowlands presented in Table 1. Boxes represent mean values with $2 \sigma$ standard deviation from the sample mean shown with error bars. BV, Belize Valley; NB, Northern Belize; PAS, Pasión; MM, Maya Mountains. Classic-period diet space after data presented by Somerville et al. 2013. Figure by Ebert.

for the sites of Altar de Sacrificios $(n=9)$, Ceibal $(n=7)$, and Tamarindito $(n=1)$ (Wright 2006). While there is variability between sites, with individual collagen $\delta^{13} \mathrm{C}$ values ranging from $-8.6 \%$ o to $-13.4 \%$, the Pasión dataset provides evidence for the highest level of maize consumption for the Preclassic. On the other hand, these sites exhibit some of the lowest mean $\delta^{15} \mathrm{~N}$ values for the Preclassic, suggesting only moderate terrestrial meat consumption (Palomo 2020:123-124).

Early and Middle Preclassic datapoints are relatively sparse, but present a picture of diet that points to diversity among early sedentary communities in the Belize Valley, northern Belize, the Maya Mountains, and the Pasión regions of the Lowlands, where published data are available $(n=65$ individuals; Figure 2 and Table 1). The lowest $\delta^{13} \mathrm{C}$ values for the Early and Middle Preclassic have been reported for the Maya Mountains region of the Lowlands. Nevertheless, the study by Kennett and colleagues (2020) suggests that maize composed at least 70 percent of dietary protein, indicating that most lowland subregions where higher $\delta^{13} \mathrm{C}$ values are reported were dominated by agricultural economies during the Early and Middle Preclassic, though with less emphasis on maize agriculture compared to the Classic period (Figure 2).

In the Belize Valley region, stable isotopic data show lower maize consumption earlier compared to northern Belize and the Pasión zones. Analyses of a small number of Middle Preclassic burials from Cahal Pech and its surrounding settlement have been subjected to isotopic analyses, with results documenting relatively low mean $\delta^{13} \mathrm{C}$ and $\delta^{15} \mathrm{~N}$ values $(-13.1 \%$ and $+8.4 \%$ ) compared to other lowland regions (Ebert et al. 2019, 2021; Powis et al. 1999; see also White et al. 2001). Though the sample size prohibits definitive statements about diet composition, isotopic data for Cahal Pech individuals, as well as one individual from Baking Pot (Hoggarth et al. 2014), generally reflect a broad diet that included the consumption of a range of domesticated plants, including maize, in addition to wild plants and animals from riparian zones along the Belize River and its tributaries.

The Pasión subregion possesses one of the largest datasets for the Middle Preclassic $(n=28)$, with all individuals from the site of Ceibal (Palomo 2020). While an average $\delta^{13} \mathrm{C}$ value of $-12.0 \pm 1.8 \%$ o suggests similar proportions of maize in the diet compared to the Belize Valley, a much higher mean $\delta^{15} \mathrm{~N}$ value $+10.8 \%$ likely reflects more meat or freshwater foods in local diets compared to other subregions (Palomo 2020:120).

In northern Belize, stable isotope data for a total of 30 individuals is available from three sites (Altun $\mathrm{Ha}, n=12$, White et al. 2001; Cuello, $n=14$, Tykot et al. 1996; K'axob, $n=4$, Henderson 2003). A mean $\delta^{13} \mathrm{C}$ value of $-12.9 \%$ for this subregion possibly suggests more investment in maize production compared to the Belize Valley, with either wild or domesticated $\mathrm{C} 3$ foods being less important protein sources than maize. The mean $\delta^{15} \mathrm{~N}$ value for northern Belize is comparable to that of the individuals from the Belize

Table 1. Mean $\delta^{13} \mathrm{C}$ and $\delta^{15} \mathrm{~N}$ values from bone collagen for the Early and Middle Preclassic by lowland region. Bold indicates the summary values for each region. SD, standard deviation.

\begin{tabular}{|c|c|c|c|c|c|c|c|}
\hline Subregion & $n$ & $\delta^{13} \mathrm{C}(\% \circ \mathrm{VPDB})$ & SD & $n$ & $\delta^{15} \mathrm{~N}(\% \circ \mathrm{AIR})$ & $\mathrm{SD}$ & Reference \\
\hline Belize Valley & 3 & -13.7 & 1.8 & 2 & +9.6 & 1.7 & \\
\hline Baking Pot & 1 & -14.9 & - & 1 & +10.8 & - & Hoggarth et al. 2014 \\
\hline Cahal Pech & 2 & -13.1 & 2.0 & 1 & +8.4 & - & Ebert et al. 2019; Powis et al. 1999 \\
\hline Maya Mountains & 4 & -14.4 & 3.9 & 4 & +6.8 & 1.6 & \\
\hline Mayahak Cab Pek & 4 & -14.4 & 3.9 & 4 & +6.8 & 1.6 & Kennett et al. 2020 \\
\hline Northern Belize & 30 & -12.9 & 1.6 & 26 & +9.6 & 1.5 & \\
\hline Altun $\mathrm{Ha}$ & 12 & -12.8 & 2.1 & 10 & +11.1 & 1.2 & White et al. 2001 \\
\hline Cuello & 14 & -12.6 & 1.0 & 12 & +8.5 & 0.8 & Tykot et al. 1996 \\
\hline K'axob & 4 & -14.5 & 0.6 & 4 & +9.3 & 0.3 & Henderson 2003 \\
\hline Pasión & 28 & -12.0 & 1.8 & 28 & +10.8 & 1.1 & \\
\hline Ceibal & 28 & -12.0 & 1.8 & 28 & +10.0 & 1.1 & Palomo 2020 \\
\hline Total & 65 & & & 60 & & & \\
\hline
\end{tabular}


Valley, perhaps indicating that similar amounts of animal protein, likely from hunting, were consumed. Nevertheless, dietary differences are documented between northern Belize sites. K'axob, for example, has the lowest mean $\delta^{13} \mathrm{C}$ and $\delta^{15} \mathrm{~N}$ values for northern Belize, possibly reflecting less reliance on $\mathrm{C} 4$ foods, as well as a subsistence economy likely dominated by terrestrial animal resources (Henderson 2003). At Altun Ha, isotopic analyses by White and colleagues (2001:381-382) of Middle Preclassic individuals buried in Structure C-13 also show less focus on the consumption of $\mathrm{C} 4$ foods compared to later (mostly Late Classic) burials at the site. On the other hand, Altun Ha has the highest $\delta^{15} \mathrm{~N}$ values of post-weaning individuals $(n=8 ;+10.6 \%$ o) for early Maya burials. Zooarchaeological data indicate that consumption of freshwater fish and fauna, and possibly marine foods, was higher compared to other northern Belize sites like Cuello and K'axob. While the authors caution that these high values may indicate that the Structure C-13 individuals came from another location closer to marine habitats, Altun Ha's close proximity $(\sim 13 \mathrm{~km})$ to the Caribbean coast and barrier reef, as well as its rich marine shell assemblage (Horn et al. 2020:438), indicates that marine food resources were easily accessible for the site's population. A more interesting question is perhaps why marine food declined during the Classic period.

Cuello has also seen some of the most intensive isotopic investigation of early Maya skeletal remains to date. While both $\delta^{13} \mathrm{C}$ and $\delta^{15} \mathrm{~N}$ values have been presented as aggregate results for the combined Preclassic sample (Tykot 2002; Tykot et al. 1996), the large numbers of Middle Preclassic individuals in the dataset warrant review. A mean bone collagen $\delta^{13} \mathrm{C}$ value of $-12.6 \%$, combined with $\delta^{13} \mathrm{C}$ data from bone and enamel apatite, indicate that the Middle Preclassic population was not as dependent on maize compared to Classic period groups. Van der Merwe and colleagues (2002:29-30) estimated that maize accounted for between 30 and 55 percent of the Preclassic human dietary protein at Cuello, though consumption of dog and armadillo, species which potentially also consumed maize, may skew these estimates.

Within the Middle Preclassic sample at Cuello, dietary differences based on sex were also documented. While females and males consumed similar types of protein, higher $\delta^{13} \mathrm{C}$ values for males could suggest that $\mathrm{C}_{4}$ foods comprised a larger proportion of their diets (Tykot et al. 1996:359). This pattern mirrors that for the Preclassic Maya lowlands more generally, with males having higher average $\delta^{13} \mathrm{C}$ values $(-12.1 \pm 1.5 \%$ ) compared to females $(-12.8 \pm 1.5 \%$ o $)$. This difference may be associated with higher maize consumption, but has also been interpreted as protein input from marine foods (White 2005). Male $\delta^{15} \mathrm{~N}$ values $(+9.8 \pm$ $1.2 \%$ ) are also higher than those for females $(+8.9 \pm 1.2 \%$ o), further suggesting increased meat/marine protein consumption (i.e., males were more carnivorous).

Skeletal markers of diet and health also shed light on the biological experience of Maya individuals. Porotic hyperostosis and cribra orbitalia, which manifest as localized areas of spongy or porous bone tissue on the surfaces of the parietals, occipital, and frontal and on the roof of the eye orbit, represent metabolic disturbances typically caused by anemia. In the Maya region, as elsewhere, signs of anemia on ancient skeletons are often attributed to dietary deficiencies related to agricultural intensification-specifically, to overreliance on maize, and iron deficiency caused by a lack of protein (Hooton 1940). However, the etiology of these lesions is far more complex than this, necessitating deep contextualization of the conditions in which they occurred. While anemia can be the direct result of poor nutrition or parasites, it can also be exacerbated when it co-occurs with other metabolic diseases, such as scurvy (White et al. 2006; Wright and Chew 1998). Furthermore, the porous bone is caused by an expansion of the diploe, indicating increased red blood cell production, which Walker and colleagues (2009) have pointed out cannot occur in situations of iron deficiency.

At Altar de Sacrificios, among the nine individuals dated to the San Felix phase (600-300 B.C.) were two infants with active porotic hyperostosis. One of the oldest human skeletons from Altar de Sacrificios (Burial 135), dated between 900 and 600 B.C. (Xe phase), is a young adult male who exhibits a healed porotic hyperostosis lesion (Saul 1972). At Cuello, porotic hyperostosis is notably reported as being absent in the Middle Preclassic crania, though the number of observable crania is not reported (Saul and Saul 1997).

Linear enamel hypoplasias (LEH) are visible as narrow, sunken bands on the tooth surface that indicate a physiological stress such as illness or malnutrition (Cucina 2011; Hillson 1996; Wright 2006; Wright and White 1996). The position of the line on the tooth can be measured to estimate the timing of the event during development, and it is common to find stress events around the time of weaning (Michael et al. 2018). In most cases, researchers simply focus on their presence and number, relating these to differential stress loads within and between groups. At Cuello, LEHs were found in relatively high frequencies in the combined Swasey-Bladen (1200-600 B.C.; 47 percent) and Mamon (600-350 B.C.; 65 percent) phases, with females showing higher frequencies in both periods (Saul and Saul 1997). Saul and Saul (1997: 154) also argue that the Cuello population had better health and nutrition during the Middle Preclassic compared to the Late Preclassic Chicanel phase (350 B.C.-A.D. 250).

Other dental pathologies are often noted as present within Middle Preclassic populations, including caries, calculus, abscesses, antemortem tooth loss, and lingual tooth surface attrition, all of which are expected in agricultural populations. Saul (1972) describes the Xe phase (900-600 B.C.) individual at Altar de Sacrificios as having most of the hallmark dental pathologies of a high carbohydrate diet, including calculus formations, caries, and antemortem tooth loss, along with healed porotic hyperostosis. At Cuello, Saul and Saul (1997) note fluctuations in caries rates between groups and over time, suggesting variation within the community. It is impossible to confidently attribute these to changes in specific social or environmental factors, given the very small sample sizes, the long temporal span they cover, and the wide range of ages of the individuals being studied. Instead, variations in oral health should be expected, as they are attributable to an array of factors that vary between environments, cultural groups, and individuals (Hillson 1996).

Other skeletal indicators of health, diet, and trauma have been reported sporadically in individuals from early sites. Saul and Saul (1997) describe cases of subperiosteal hemorrhages resulting from infections and osteoarthritis at Cuello. They also report high frequencies of tibial abnormalities, including anterior-posterior bowing and cortical expansion, which they attribute to endemic syphilis. It should be noted, however, that while relatively common in other areas of the Americas (Powell and Cook 2005), there has been very little evidence of syphilis in the Maya area prior to European contact, and the few possible cases identified thus far are most likely yaws (T. pallidum pertenue), a related treponemal disease (Wright 2006:197). No trauma was reported among the Middle Preclassic individuals, in contrast to a variety of healed postcranial fractures and two cases of healed cranial trauma from 
Late Preclassic individuals. At Altar de Sacrificios, the Middle Preclassic Burial 135 had a healed transverse fracture on the left clavicle (Saul 1972). Among the San Felix phase (600-300 B.C.) burials at Altar de Sacrificios, two adult males were found with ossified subperiosteal hemorrhages, and one elderly adult had a healed cranial lesion, all indicating some form of trauma in life.

Another study of Mesoamerican biocultural dynamics during the Preclassic period by Rodríguez (2017) focused on comparisons of several physiological and nutritional indicators in small samples of Middle and Late Preclassic skeletons from Chiapa de Corzo and Caucel, Mexico; Ceibal and Altar de Sacrificios, Guatemala; and Barton Ramie, Belize. Rodríguez found no significant differences in porotic hyperostosis, non-specific periosteal reactions, linear enamel hypoplasias, caries, abscesses, and dental wear.

Due to the typically poor bone preservation at Early and Middle Preclassic sites, reporting of skeletal pathology data is inconsistent. Thus, lesions resulting from disease and trauma are often reported when present, but we lack appropriate frequency data to carry out any sort of comparative analyses. Instead, these data are most useful in carrying out osteobiographies, which utilize contextualized skeletal data to describe the life experiences of individuals living in the past. This approach has a long history in Mesoamerica (Romero Molina 1934, 1937; Rubín de la Borbolla 1969; Saul 1972; Saul and Saul 1989) and recently has seen a resurgence of interest in the bioarchaeological community, thanks to new methodologies and theoretical frameworks that allow more complete and meaningful reconstruction and contextualization of life histories (Hosek and Robb 2019).

\section{BODY MODIFICATION}

As discussed above, there have been few syntheses of skeletal data that distinguish between the Early, Middle, and Late Preclassic periods. A notable exception is Tiesler's $(2012,2014)$ work on cranial and dental modification. In her nearly exhaustive synthesis of cranial modification practices from across Mesoamerica, Tiesler discusses its ancient origins, citing previous studies that describe the presence of tabular erect modifications on six individuals from greater Mesoamerica dating to 8800-7000 years B.P. (Tiesler 2014:163). Following Romano, she posits that the practice among hunter-gatherers likely stemmed from cradleboard use. In the Preclassic, with the rise of agriculture and settled villages, as well as territoriality and social stratification, a diversity of forms arose through the use of both compression cribs and head devices. Two Middle Preclassic individuals from Kaminaljuyu, for instance, showed frontal flattening that appears to have been an inadvertent consequence of tumpline use (Tiesler 2014:172).

The earliest skeletal evidence of cranial modification in the Maya area comes from Middle Preclassic contexts at the sites of Cuello, Belize (Hammond et al. 2002) and Altar de Sacrificios (Saul 1972); however, despite a lack of evidence for it among the few, poorly preserved remains dating to the Early Preclassic, these groups almost certainly practiced cranial modification, given its ubiquity in the region before and after that period. In general, Tiesler notes that cranial modification in the Preclassic appears to be less frequent and diverse, increasing dramatically in the Classic period because of new techniques. Though Tiesler's Maya Middle Preclassic sample is quite small $(n=17)$, she notes the presence of ten individuals with "pseudo-circular fronto-occipital" modifications, a style that Romano attributed to the Olmec, based on its resemblance to the forms of the anthropomorphic Olmec head sculptures and figurines (Romano 1980; Tiesler 2010, 2014). Among the 1,242 crania included in Tiesler's study, she found only ten examples of this form, all of which predate A.D. 250 and are from geographically dispersed major Preclassic political or exchange centers in the northern Yucatán, the Southern Lowlands, and Chiapas. The four Middle Preclassic examples (predating A.D. 450) come from Altar de Sacrificios (Burial 124), Ceibal (Burial 11), Caucel (Burial 1), and Pampa el Pajón (Burial 1). They have no clear association with sex or social status, and Tiesler (2014:179) argues that the presence of these forms in the Maya area, most examples of which post-date the fall of the Olmec (ca. 400 B.C.), "speaks more of syncretism and reinterpretation of Olmec heartland ideology than direct imposition."

The earliest known dental modifications, in the form of simple filing, appear in the Maya area during the Early Bladen phase (900-800 B.C.) of the Middle Preclassic period at Cuello Belize (Saul and Saul 1997:45-46). Burial 11 at Ceibal, dated to the Middle Preclassic, displays Ik form (T-shaped) dental filing (Tiesler 2010:296), which remains common throughout time across the Maya area. Javier Romero Molina (1958) describes early material evidence of Maya dental practices, such as inlays in the drilled teeth of an individual who lived at the central lowland site of Uaxactún (Peten, Guatemala) during the Mamon phase (600-350 B.C.).

\section{LIMITATIONS OF THE DATASET}

A review of the dataset presented in Supplementary Table 1 reveals several impediments to creating meaningful syntheses of the available skeletal data, so it is perhaps worthwhile to include a discussion of the biases in our dataset, which will be familiar to bioarchaeologists working in the region. First and foremost, Maya burials dating to the Early and Middle Preclassic period are relatively rare. In part, this reflects biases by archaeologists towards researching later time periods, but also the fact that Preclassic contexts (and the burials contained within them) are often deeply buried beneath (and sometimes destroyed by) later Classic period ( A.D. 250-900/1000) monumental architecture, making them relatively inaccessible. As a result, excavations targeting early architecture often necessitate time-consuming documentation and removal of overlying layers, making large-scale exposure of these contexts problematic (Chase and Chase 2006:96; Hammond et al. 1995:121). At many sites, the earliest deposits are known only by what appears at the bottom of narrow test pits. Of the 40 sites with Early or Middle Preclassic burials, only eight had ten or more individuals. Even at sites with larger sample sizes, burials tend to come from a limited number of discrete contexts; for instance, the relatively large sample of 45 Middle Preclassic individuals from Altun Ha all come from a single non-residential structure (Pendergast 1982: 170). Thus, these cannot be treated as representative of a general population, but instead are likely some specific, culturally defined social subunit within the larger community.

Second, our current models of mortuary and biological variability in these early contexts are greatly biased by the limited research that is published. Our relatively small samples are spread across a significant geographic and temporal range, and this makes it difficult to generate a coherent picture of diversity among Early and Middle Preclassic communities. Of all the sites with mortuary contexts dating to the Middle Preclassic, Cuello has received by far the most attention, and for that reason our picture of the entire period is largely influenced by data from this site, as well as a few other 
Belizean sites, including K'axob, Santa Rita Corozal, and Cahal Pech. However, recent research at Ceibal, located in the Pasión region of Guatemala, has overturned previous models by demonstrating a much greater level of complexity, highlighting the importance of regional variation in mortuary practices, diet, and mobility (Palomo 2020; Palomo et al. 2017).

Third, much of the data from early skeletons is frustratingly difficult to synthesize, since interpretations are restricted by temporal associations. Analyses of skeletal remains for the Preclassic in general have rarely been combined with radiocarbon dating, impeding precise temporal assignments necessary to look at changes over time. Instead, almost all dates for these burials are based on ceramic and/or stratigraphic associations, rather than AMS radiocarbon dates. Burials are therefore lumped into ceramic phases encompassing several hundred years, preventing adequate contextualization of skeletal data.

Fourth, skeletal data for these early individuals are generally descriptive in nature, in large part due to the poor preservation that hampers consistent visual assessment of indicators of sex, age, and cranial/dental modification. Paleopathological and stable isotopic data, most often reported as summary data (e.g., averages of values, aggregates of all Preclassic individuals), have been collected over a span of many decades by investigators using a variety of different methodologies, thus making comparisons difficult or impossible. Bioarchaeologists walk a fine line, where we try to move beyond simple description of individuals by amalgamating them into groups for comparative analyses, while also attempting to maintain the social, environmental, and geographic distinctions among our samples that form the basis of anthropological inquiry. For the purposes of this review, we have discussed general trends, using examples where they are available, and focusing primarily on highlighting the significant variability present within and among these communities.

\section{CONCLUSIONS AND FUTURE DIRECTIONS}

This review identifies some intriguing themes among Early and Middle Preclassic skeletons in the Maya area. Unfortunately, it is impossible at this point to make definitive statements about the nature of biological and mortuary variability of these early groups, due in large part to a lack of chronological resolution, poor preservation, and reliance on small sample sizes that reflect diverse mortuary customs (rather than being representative of a general population). We note with great enthusiasm, however, that bioarchaeology is currently benefiting from rapid methodological advances and that several ongoing projects are actively working to aid in providing a wider range of biological data. These new data will help to overcome some of the limitations inherent in current samples and increase our ability to reach beyond the Late Preclassic to investigate the origins of the transition to social complexity. While a full review of such research within the broader field of bioarchaeology is beyond the scope of this article, we highlight a couple of examples below to demonstrate how new data will impact the study of the earliest Maya groups.

First, as AMS radiocarbon dating methods and calibration curves are continually being improved (e.g., Price et al. 2021; Reimer et al. 2020), early burial dates assigned based on archaeological associations can be tested. There is now underway a project (Maya Bone Project) aimed at directly dating large numbers of burials throughout the Maya region. Dates generated from this project and others have already helped to confirm the early associations of some burials, as well as to identify burials that were incorrectly assigned Middle Preclassic dates (e.g., Ebert and Awe 2021). While many early burials have no preserved collagen, thus preventing ${ }^{14} \mathrm{C}$ dating, data generated from wellpreserved burials are helping to refine ceramic chronologies based on ceramic types found in association with the skeletons, thus facilitating comparative analyses (Ebert et al. 2019, 2021; Hoggarth et al. 2014). This work will no doubt impact many of the burial dates presented in our summary table, so investigators utilizing this list in the future should be alert to subsequent research that we anticipate will result in revisions.

Another potentially transformational source of new data is ancient DNA (aDNA). As methods for extraction, sequencing, and analysis are rapidly improving, prices for this work are plummeting, allowing sampling from a greater number of individuals and more complete sequencing of individual genomes. Currently, most genomic research in the Maya area has focused on the initial peopling of the region during the Late Pleistocene and Archaic (e.g., Chatters et al. 2014; Posth et al. 2018; Roca-Rada et al. 2020). The creation of large reference samples will allow comparative analyses that will explore a range of other specific questions about Maya history and social organization. There has been a number of recent critiques of aDNA research that have accompanied the hype surrounding it, and we agree that these new data are only as good as the questions we ask of them, necessitating deep contextualization provided by archaeology to examine the meaning of patterns of genomic variability (Michael et al. 2021). New aDNA research is increasingly focused on specific social questions, including how patterns of genetic relatedness correlate to specific cultural practices, such as body modifications and mortuary rituals (Verdugo et al. 2017, 2020a, 2020b), as well as exploring and mapping patterns of relatedness within and between communities that can also be used to estimate effective population sizes. Used in combination with stable isotope analyses, aDNA can help to identify patterns of migration and mobility (Freiwald 2020). While many early individuals will not have preserved tissues suitable for DNA extraction, modeling based on data from later groups will provide valuable information about the genetic make-up of ancestral groups (González-Oliver et al. 2019).

Finally, perhaps the largest issue limiting bioarchaeological investigation of these early communities is the relative paucity of early burials. However, there are several archaeological projects under way that are focusing on excavations of Early and Middle Preclassic contexts, at the sites of Xunantunich (Brown et al. 2018), Cahal Pech (Ebert and Awe 2021; Ebert et al. 2019), and Pacbitun (Powis 2020) in the Belize River Valley; rock shelter sites in the Maya Mountains of southern Belize (Kennett et al. 2020; Prufer et al. 2020); Nixtun-Ch'ich' in Peten, Guatemala (Pugh and Rice 2017; Rice 2020); various sites in the Puuc region of Mexico (Andrews et al. 2018); and Ceibal in the Pasión region of Guatemala (Palomo 2020; Palomo et al. 2017). Guided by the preliminary studies reviewed here, these new investigations can begin to document the sources of variations in skeletal data, asking critical questions about the biocultural forces that shaped Maya civilization.

\section{SUPPLEMENTARY MATERIAL}

To view supplementary material for this article, please visit https:// doi.org/10.1017/S0956536121000456 


\section{RESUMEN}

Este capítulo presenta una revisión de los restos óseos maya tempranos encontrados hasta ahora. Nosotros hemos compilado una lista de más de 398 entierros mayas que fechan de los períodos preclásico temprano y medio. Estos sitios están distribuidos por toda la región maya y los datos permiten realizar síntesis descriptivas básicas sobre el comportamiento mortuorio temprano, así como aspectos de salud y dieta. La mala preservación y el análisis e informe diferente limitan severamente el alcance de la posible interpretación, pero se espera que esta revisión estimule la investigación coordinada de la biología de los grupos tempranos.

\section{ACKNOWLEDGMENTS}

Many thanks to our generous colleagues for their help with the burial inventories and with comments on early drafts: Jaime Awe, Kat Brown, Adrian Chase, Arlen Chase, Andrea Cucina, Carolyn Freiwald, Julie Hoggarth,

\section{REFERENCES}

Aimers, James, Terry Powis, and Jaime Awe

2000 Preclassic Round Structures of the Upper Belize River Valley. Latin American Antiquity 11:71-86.

Ambrose, Stanley H., and John Krigbaum

2003 Bone Chemistry and Bioarchaeology. Journal of Anthropological Archaeology 22:193-199.

Andrews, E. Wyllys, V, George J. Bey III, and Christopher Gunn

2018 The Earliest Ceramics of the Northern Maya Lowlands. In Pathways to Complexity: A View from the Maya Lowlands, edited by M. Kathryn Brown and George J. Bey III, pp. 49-86. University of Florida Press, Gainesville.

Anselmetti, Flavio S., David A. Hodell, Daniel Ariztegui, Mark Brenner, and

Michael F. Rosenmeier

2007 Quantification of Soil Erosion Rates Related to Ancient Maya Deforestation. Geology 35:915-918.

Awe, Jaime J.

1992 Dawn in the Land Between the Rivers: Formative Occupation at Cahal Pech, Belize and Its Implications for Preclassic Occupation in the Central Maya Lowlands. Unpublished Ph.D. dissertation, University College London, London.

Blake, Michael

2015 The Archaeology of Maize. In Maize for the Gods: Unearthing the 9,000-Year History of Corn, by Michael Blake, pp. 17-36. University of California Press, Berkeley.

Bocherens, Herve, and Dorothée Drucker

2003 Trophic Level Isotopic Enrichment of Carbon and Nitrogen in Bone Collagen: Case Studies from Recent and Ancient Terrestrial Ecosystems. International Journal of Osteoarchaeology 13:46-53.

Brady, James

1995 A Reassessment of the Chronology and Function of Gordo's Cave \#3. Ancient Mesoamerica 6:29-38.

Brown, M. Kathryn, Jaime Awe, and James Garber

2018 The Role of Ritual in the Foundation of Social Complexity in the Belize River Valley. In Pathways to Complexity: A View from the Maya Lowlands, edited by M. Kathryn Brown and George Bey III, pp. 87-116. University Press of Florida, Gainesville.

Chase, Diane Z., and Arlen F. Chase

2006 The Dawn of Maya Civilization: Preclassic Archaeology From Santa Rita Corozal. Research Reports in Belizean Archaeology 3:85-100.

Chase, Adrian, Diane Chase, and Arlen Chase

2018 Situating Preclassic Interments and Fire-Pits at Santa Rita Corozal, Belize. Research Reports in Belizean Archaeology 15:159-167.

Chatters, James, Douglas Kennett, Yemane Asmerom, Brian Kemp, Victor Polyak, Alberto Blank, Patricia Beddows, Eduard Reinhardt, Joaquín Arroyo, Deborah Bolnick, Ripan Malhi, Brendan Culleton, Pilar Luna, Dominique Rissolo, Shanti Morell-Hart, and Thomas Stafford Jr.

2014 Late Pleistocene Human Skeleton and mtDNA Link Paleoamericans and Modern Native Americans. Science 344(6185):750-754.

Cohen, Mark N., and George J, Armelagos (editors)

1984 Paleopathology at the Origins of Agriculture. Academic Press, Orlando.
Aubree Marshall, Juan Manuel Palomo Mijangos, Katherine Miller Wolf, Vera Tiesler, and two anonymous reviewers.

Cohen, Mark N., and Gillian M.M. Crane-Kramer (editors)

2007 Ancient Health: Skeletal Indicators of Economic and Political Intensification. University of Florida Press, Gainesville.

Cucina, Andrea

2011 Maya Sub-Adult Mortality and Individual Physiological Frailty: An Analysis of Infant Stress by Means of Linear Enamel Hypoplasia. Childhood in the Past 4:105-116.

DeNiro, Michael J., and Samuel Epstein

1978 Influence of Diet on the Distribution of Carbon Isotopes in Animals. Geochimica et Cosmochimica Acta 42:495-506.

1981 Influence of Diet on the Distribution of Nitrogen Isotopes in Animals. Geochimica et Cosmochimica Acta 45:341-351.

Doebly, John

2004 The Genetics of Maize Evolution. Annual Review of Genetics 38: 37-59.

Doyle, James

2020 The Southern Maya Lowlands in the Late Preclassic. In The Maya World, edited by Scott R. Hutson and Traci Ardren, pp. 43-62. Routledge, Abingdon.

Ebert, Claire E., and Jaime J. Awe

2021 Comparing Preclassic Sequences at Cahal Pech, Belize: Reply to Horn. Latin American Antiquity 32:442-444.

Ebert, Claire, Julie Hoggarth, Jaime Awe, Brendan Culleton, and Douglas Kennett

2019 The Role of Diet in Resilience and Vulnerability to Climate Change Among Early Agricultural Communities in the Maya Lowlands. Current Anthropology 60:589-601.

Ebert, Claire E., Asta J. Rand, Kirsten Green-Mink, Julie A. Hoggarth,

Carolyn Freiwald, Jaime J. Awe, Willa R. Trask, Jason Yaeger, M. Kathryn

Brown, Christophe Helmke, Rafael A. Guerra, Marie Danforth, and Douglas

J. Kennett

2021 Sulfur Isotopes as a Proxy for Human Diet and Mobility from the Preclassic Through Colonial Periods in the Eastern Maya Lowlands. PLOS ONE 16(8):e0254992.

Freiwald, Carolyn

2011 Maya Migration Networks: Reconstructing Population Movement in the Belize River Valley During the Late and Terminal Classic. Ph.D. dissertation, Department of Anthropology, University of WisconsinMadison, Madison.

2018 Mobility and Diet in the Belize River Valley: A Resource Guide. In The Belize Valley Archaeological Reconnaissance Project: A Report of the 2017 Field Season, edited by Claire E. Ebert, Julie A. Hoggarth, and Jaime J. Awe, pp. 357-386. Institute of Archaeology, Baylor University, Waco.

2020 Migration and Mobility in the Eastern Maya Lowlands. In The Maya World, edited by Scott R. Hutson and Traci Ardren, pp. 203-222. Routledge, Abingdon.

Garza, Sergio, James Brady, and Christian Christensen

2001 Balam Na Cave 4: Implications for Understanding Preclassic Cave Mortuary Practices. California Anthropologist 28(1):15-21. 
González, Arturo H., Alejandro Terrazas, Wolfgang Stinnesbeck, Martha E. Benavente, Jerónimo Avilés, Carmen Rojas, José Manuel Padilla, Adriana Velásquez, Eugenio Acevez, and Eberhard Frey

2013 The First Human Settlers on the Yucatan Peninsula: Evidence from Drowned Caves in the State of Quintana Roo (South Mexico). In Paleoamerican Odyssey, edited by Kelly E. Graf, Caroline V. Ketron, and Michael R. Waters, pp. 323-337. Texas A\&M University, College Station.

González-Oliver, Angélica, Dircé Pineda-Vázquez, Ernesto

Garfias-Morales, Isabel De La Cruz-Laina, Luis Medrano-González,

Lourdes Márquez-Morfín, and Allan Ortega-Muñoz

2019 Genetic Overview of the Maya Populations: Mitochondrial DNA Haplogroups. Human Biology 90:281-300.

Gordon, Claire C., and Jane E. Buikstra

1981 Soil pH, Bone Preservation, and Sampling Bias at Mortuary Sites. American Antiquity 46:566-571.

Hammond, Norman

1995 Ceremony and Society at Cuello: Preclassic Ritual Behavior and Social Differentiation. In The Emergence of Classic Maya Civilization, edited by Nicholas Grube, pp. 49-60. Acta Mesoamericana 8. Verlag von Fleming, Möckmühl.

Hammond, Norman, Amanda Clarke, and Cynthia Robin

1991 Middle Preclassic Buildings and Burials at Cuello, Belize: 1990 Investigations. Latin American Antiquity 2:352-363.

Hammond, Norman, Amanda Clarke, and Francisco Estrada Belli

1992 Middle Preclassic Maya Buildings and Burials at Cuello, Belize. Antiquity 66:955-964.

Hammond, Norman, Amanda Clarke, and Sara Donaghey

1995 The Long Goodbye: Middle Preclassic Maya Archaeology at Cuello, Belize. Latin American Antiquity 6:120-128.

Hammond, Norman, Julie Saul, and Frank Saul

2002 Ancestral Faces: A Preclassic Maya Skull-Mask from Cuello, Belize. Antiquity 76:951-952.

Henderson, Hope

2003 The Organization of Staple Crop Production at K'axob, Belize. Latin American Antiquity 14:469-496.

Hernández Espinoza, Olga P., and Lourdes Márquez Morfín

2015 Maya Paleodemographics: What Do We Know? American Journal of Human Biology 27:747-757.

Hill, Ethan C., Emily Moes, Willa R. Trask, Emily Kate, Catriona

McKenzie, Heather J.H. Edgar, Douglas J. Kennett, and Keith M. Prufer

2018 Current Research on Late Pleistocene and Early Holocene Human Remains from the Bladen Nature Reserve in Southern Belize. American Journal of Physical Anthropology 165:120.

Hillson, Simon

1996 Dental Anthropology. Cambridge University Press, Cambridge.

Hodell, David A., Rhonda L. Quinn, Mark Brenner, and George Kamenov

2004 Spatial Variation of Strontium Isotopes (87Sr/86Sr) in the Maya Region: A Tool for Tracking Ancient Human Migration. Journal of Archaeological Science 31:585-601.

Hoggarth, Julie, Brendan Culleton, Jaime Awe, and Douglas Kennett

2014 Questioning Postclassic Continuity at Baking Pot, Belize: Using AMS ${ }^{14} \mathrm{C}$ Direct Dating of Human Burials. Radiocarbon 56:1057-1075.

Hooton, Earnest A.

1940 Skeletons from the Cenote of Sacrifice at Chichén Itzá. In The Maya and their Neighbors, edited by Clarence L. Hay, Ralph L. Linton, Samuel K. Lothrop, Harry L. Shapiro, and George C. Vaillant, pp. 272-291. Appleton-Century, New York.

Horn, Sherman W. III, Terry G. Powis, and David M. Pendergast

2020 Of Watery Rocks and Slumbering Crocs: Reassessing Middle Preclassic Occupation at Altun Ha and Lamanai, Belize. Journal of Field Archaeology 45:428-444.

Hosek, Lauren, and John Robb

2019 Osteobiography: A Platform for Bioarchaeological Research. Bioarchaeology International 3:1-15.

Inomata, Takeshi, Daniela Triadan, Kazuo Aoyama, Victor Castillo, and

Hitoshi Yonenobu

2013 Early Ceremonial Constructions at Ceibal, Guatemala, and the Origins of Lowland Maya Civilization. Science 340:467-471.

Inomata, Takeshi, Jessica MacLellan, and Melissa Burham

2015 The Construction of Public and Domestic Spheres in the Preclassic Maya Lowlands. American Anthropologist 117:519-534.

Joyce, Rosemary

1999 Social Dimensions of Pre-Classic Burials. In Social Patterns in
Pre-Classic Mesoamerica, edited by David Grove and Rosemary Joyce, pp. 15-48. Dumbarton Oaks Research Library and Collection, Washington, DC.

Kennett, Douglas J., Keith M. Prufer, Brendan J. Culleton, Richard J.

George, Mark Robinson, Willa R. Trask, Gina M. Buckley, Emily Moes,

Emily J. Kate, Thomas K. Harper, Lexi O'Donnell, Erin E. Ray, Ethan C.

Hill, Asia Alsgaard, Christopher Merriman, Clayton Meredith, Heather J. H.

Edgar, Jaime J. Awe, and Said M. Gutierrez

2020 Early Isotopic Evidence for Maize as a Staple Grain in the Americas. Science Advances 6:1-12.

Kistler, Logan, S. Yoshi Maezumi, Jonas Gregorio De Souza, Natalia A.S. Przelomska, Flaviane Malaquias Costa, Oliver Smith, Hope Loiselle, Jazmín Ramos-Madrigal, Nathan Wales, Eduardo Rivail Ribeiro, Ryan R. Morrison, Claudia Grimaldo, Andre P. Prous, Bernardo Arriaza, M. Thomas P. Gilbert, Fabio de Oliveira Freitas, and Robin G. Allaby

2018 Multiproxy Evidence Highlights a Complex Evolutionary Legacy of Maize in South America. Science 362(6420):1309-1313.

Larsen, Clark Spencer, Christopher J. Knüsel, Scott D. Haddow, Marin A. Pilloud, Marco Milella, Joshua W. Sadvari, Jessica Pearson, Christopher B. Ruff, Evan M. Garofalo, Emmy Bocaege, Barbara J. Betz, Irene Dori, and Bonnie Glencross

2019 Bioarchaeology of Neolithic Çatalhöyük Reveals Fundamental Transitions in Health, Mobility, and Lifestyle in Early Farmers. PNAS 116:12615-12623.

Lowe, Gareth

1964 Burial Customs at Chiapa de Corzo. In The Archaeological Burials at Chiapa de Corzo and Their Furniture, edited by Pierre Agrinier, pp. 65-75. Papers of the New World Archaeological Foundation 16. Brigham Young University Press, Provo.

McAnany, Patricia

1995 Living with the Ancestors: Kinship and Kingship in Ancient Maya Society. University of Texas Press, Austin.

2004 Situating K'axob Within Formative Period Lowland Maya Archaeology. In K'axob: Ritual, Work, and Family in an Ancient Maya Village, edited by Patricia A. McAnany, pp. 1-9. Cotsen Institute of Archaeology, Los Angeles.

McAnany, Patricia, and Sandra López

1999 Re-Creating the Formative Maya Village of K'axob: Chronology, Ceramic Complexes, and Ancestors in Architectural Context. Ancient Mesoamerica 10:147-168.

McAnany, Patricia, Rebecca Storey, and Angela Lockard

1999 Mortuary, Ritual, and Family Politics at Formative and Early Classic K'axob, Belize. Ancient Mesoamerica 10:129-146.

Michael, Amy R., Gabriel D. Wrobel, and Jack Biggs

2018 Understanding Late Classic Maya Mortuary Ritual in Caves: Dental Evidence of Health from Macro- and Microscopic Defects and Caries. In Bioarchaeology of Pre-Columbian Mesoamerica: An Interdisciplinary Approach, edited by Cathy Willermet and Andrea Cucina, pp. 133-158. University of Florida Press, Gainesville.

Michael, Amy, Jennifer Bengtson, and Samantha Blatt

2021 Genes, Race, Ancestry, and Identity in Forensic Anthropology: Historical Perspectives and Contemporary Concerns. Forensic Genomics 1:41-46.

Palomo, Juan Manuel

2020 Local Community and Foreign Groups: Political Changes in the Ancient Maya Center of Ceibal, Guatemala. Unpublished Ph.D. dissertation. School of Anthropology, University of Arizona, Tucson.

Palomo, Juan, Takeshi Inomata, and Daniela Triadan

2017 Mortuary Rituals and Cranial Modifications at Ceibal: From the Early Middle Preclassic to the Terminal Classic Period. Ancient Mesoamerica 28:305-327.

Parker, Evan, George J. Bey III, and Tomás Gallareta Negrón

2020 Centering the Early Maya Village: A Middle Preclassic Cosmogenic Jade Offering from Paso del Macho, Yucatán, México. Paper presented at the 2020 Mesoamerica Meetings, January 17, Austin.

Pendergast, David

1982 Excavations at Altun Ha, Belize, 1964-1970, Volume 2. Royal Ontario Museum, Toronto.

Pihasi, Ron, and Jay T. Stock (editors)

2011 Human Bioarchaeology of the Transition to Agriculture. Wiley, West Sussex.

Piperno, Dolores R.

2011 The Origins of Plant Cultivation and Domestication in the New 
World Tropics: Patterns, Process, and New Developments. Current Anthropology 52:S453-S470.

Pohl, Mary D., Kevin O. Pope, John G. Jones, John S. Jacob, Dolores R. Piperno, Susan D. deFrance, David L. Lentz, John A. Gifford, Marie E. Danforth, and J. Kathryn Josserand

1996 Early Agriculture in the Maya Lowlands. Latin American Antiquity 7:355-372.

Posth, Cosimo, Nathan Nakatsuka, Iosif Lazaridis, Pontus Skoglund, Swapan Mallick, Thiseas C. Lamnidis, Nadin Rohland, Kathrin Nägele, Nicole Adamski, Emilie Bertolini, Nasreen Broomandkhoshbacht, Alan Cooper, Brendan J. Culleton, Tiago Ferraz, Matthew Ferry, Anja Furtwängler, Wolfgang Haak, Kelly Harkins, Thomas K. Harper, Tábita Hünemeier, Ann Marie Lawson, Bastien Llamas, Megan Michel, Elizabeth Nelson, Jonas Oppenheimer, Nick Patterson, Stephan Schiffels, Jakob Sedig, Kristin Stewardson, Sahra Talamo, Chuan-Chao Wang, Jean-Jacques Hublin, Mark Hubbe, Katerina Harvati, Amalia Nuevo Delaunay, Judith Beier, Michael Francken, Peter Kaulicke, Hugo Reyes-Centeno, Kurt Rademaker, Willa R. Trask, Mark Robinson, Said M. Gutierrez, Keith M. Prufer, Domingo C. Salazar-García, Eliane N. Chim, Lisiane Müller Plumm Gomes, Marcony L. Alves, Andersen Liryo, Mariana Inglez, Rodrigo E. Oliveira, Danilo V. Bernardo, Alberto Barioni, Veronica Wesolowski, Nahuel A. Scheifler, Mario A. Rivera, Claudia R. Plens, Pablo G. Messineo, Levy Figuti, Daniel Corach, Clara Scabuzzo, Sabine Eggers, Paulo DeBlasis, Markus Reindel, César Méndez, Gustavo Politis, Elsa Tomasto-Cagigao,

Douglas J. Kennett, André Strauss, Lars Fehren-Schmitz, Johannes Krause, and David Reich

2018 Reconstructing the Deep Population History of Central and South America. Cell 175:1185-1197.

Powell, Mary Lucas, and Della C. Cook (editors)

2005 The Myth of Syphilis: The Natural History of Treponematosis in North America. University Press of Florida, Gainesville.

Powis, Terry G.

2020 Middle Preclassic Maya Community Organisation at Pacbitun, Belize. In An Archaeological Reconstruction of Ancient Maya Life at Pacbitun, Belize, edited by Terry G. Powis, Sheldon Skaggs, and George J. Micheletti, pp. 25-40. BAR International Series 2970. BAR Publishing, Oxford.

Powis, Terry G., Norbert Stanchly, Christine White, Paul Healy, Jaime Awe, and Fred Longstaffe

1999 A Reconstruction of Middle Preclassic Maya Subsistence Economy at Cahal Pech, Belize. Antiquity 73:364-376.

Price, Michael Holton, José M. Capriles, Julie A. Hoggarth, R. Kyle

Bocinsky, Claire E. Ebert, and James Holland Jones

2021 End-to-End Bayesian Analysis for Summarizing Sets of Radiocarbon Dates. Journal of Archaeological Science 135:105473.

Price, T. Douglas, James H. Burton, and R. Alexander Bentley

2002 The Characterization of Biologically Available Strontium Isotope Ratios for the Study of Prehistoric Migration. Archaeometry 44: $117-135$.

Price, T. Douglas, James H. Burton, Robert J. Sharer, Jane E. Buikstra, Lori

E. Wright, Loa P. Traxler, and Katherine A. Miller

2010 Kings and Commoners at Copan: Isotopic Evidence for Origins and Movement in the Classic Maya Period. Journal of Anthropological Archaeology 29:15-32.

Price, T. Douglas, James H. Burton, Paul D. Fullagar, Lori E. Wright, Jane E. Buikstra, and Vera Tiesler

2015 Strontium Isotopes and the Study of Human Mobility Among the Ancient Maya. In Archaeology and Bioarchaeology of Population Movement Among the Prehispanic Maya, edited by Andrea Cucina, pp. 119-132. Springer, Cham.

Prufer, Keith M., Mark Robinson, and Douglas J. Kennett

2020 Recent Research in the Bladen Nature Reserve: The Preceramic Occupations of Mayahak Cab Pek and Saki Tzul Rockshelters. Research Reports in Belizean Archaeology 17:199-208.

Pugh, Timothy W., and Prudence M. Rice

2017 Early Urban Planning, Spatial Strategies, and the Maya Gridded City of Nixtun-Ch'ich', Petén, Guatemala. Current Anthropology 58: 576-603.

Redfern, Rebecca C

2020 Changing People, Changing Settlements? A Perspective on Urbanism from Roman Britain. In The Bioarchaeology of Urbanization, edited by Tracy K. Betsinger and Sharon N. DeWitte, pp. 25-47. Springer, Cham.
Reimer, Paula J., William E.N. Austin, Edouard Bard, Alex Bayliss, Paul G. Blackwell, Christopher Bronk Ramsey, Martin Butzin, Hai Cheng, R. Lawrence Edwards, Michael Friedrich, Pieter M. Grootes, Thomas P. Guilderson, Irka Hajdas, Timothy J. Heaton, Alan G. Hogg, Konrad A. Hughen, Bernd Kromer, Sturt W. Manning, Raimund Muscheler, Jonathan G. Palmer, Charlotte Pearson, Johannes Van Der Plicht, Ron W. Reimer, David A. Richards, E. Marian Scott, John R. Southon, Christian S. M. Turney, Lukas Wacker, Florian Adolphi, Ulf Büntgen, Manuela Capano, Simon M. Fahrni, Alexandra Fogtmann-Schulz, Ronny Friedrich, Peter Köhler, Sabrina Kudsk, Fusa Miyake, Jesper Olsen, Frederick Reinig, Minoru Sakamoto, Adam Sookdeo, and Sahra Talamo

2020 The IntCal20 Northern Hemisphere Radiocarbon Age Calibration Curve (0-55 cal kBP). Radiocarbon 62:725-757.

Rice, Prudence M.

2015 Middle Preclassic Interregional Interaction and the Maya Lowlands. Journal of Archaeological Research 23:1-47.

2020 Crocodiles, Sharks, and Some Speculations in Central Peten Preclassic History. Ancient Mesoamerica 31:230-247.

2021 In Search of Middle Preclassic Lowland Maya Ideologies. Journal of Archaeological Research 29:1-46.

Robin, Cynthia, and Norman Hammond

1991 Ritual and Ideology. In Cuello: An Early Maya Community in Belize, edited by Norman Hammond, pp. 204-234. Cambridge University Press, Cambridge.

Roca-Rada, Xavier, Yassine Souilmi, João C. Teixeira, and Bastien Llamas 2020 Ancient DNA Studies in Pre-Columbian Mesoamerica. Genes 11: 1346 .

Rodríguez, Mónica

2017 Dinámicas bioculturales en Mesoamérica durante el periodo Preclásico como parte del origen de la complejida social. Enfoques bioarqueológicos: Aspectos biológicos y funerarios. Unpublished Ph.D. dissertation. Universidad Nacional Autónoma de México, Mexico City.

Romano, Arturo

1980 Appendix 3: The Skull from El Pajón, Chiapas. In Pampa El Pajón: An Early Estuarine Site, Chiapas, Mexico, edited by María Paillés, pp. 95-114. New World Archaeological Foundation, University of Brigham Young, Provo.

Romero Molina, Javier

1934 Estudio de la osamenta procedente de las excavaciones de la Plaza del Seminario. Anales del Museo Nacional de Arqueología, Historia y Etnografía 26(1):287-290.

1937 Estudio de los entierros de la pirámide de Cholula. Anales del Instituto Nacional de Antropología e Historia 5(2):5-36.

1958 Mutilaciones dentarias prehispánicas de México y América en general. Instituto Nacional de Antropología e Historia, Mexico City.

Rosenswig, Robert M., Deborah M. Pearsall, Marilyn A. Masson, Brendan J. Culleton, and Douglas J. Kennett

2014 Archaic Period Settlement and Subsistence in the Maya Lowlands: New Starch Grain and Lithic Data from Freshwater Creek, Belize. Journal of Archaeological Science 41:308-321.

Rubín de la Borbolla, Daniel F.

1969 La osamenta humana encontrada en la Tumba 7. In El tesoro de Monte Albán, edited by Alfonso Caso, pp. 275-324. Memorias del Instituto Nacional de Antropología e Historia 3. Instituto Nacional de Antropología e Historia, Mexico City.

Saul, Frank

1972 The Human Skeletal Remains of Altar de Sacrificios: An Osteobiographic Analysis. Papers of the Peabody Museum of Archaeology and Ethnology 63, No. 2. Harvard University, Cambridge.

Saul, Frank, and Julie Saul

1989 Osteobiography: A Maya Example. In Reconstruction of Life from the Skeleton, edited by Mehmet Yaşar İşcan and Kenneth A.R. Kennedy, pp. 287-302. Alan R. Liss, New York.

1991 The Preclassic Population of Cuello. In Cuello: An Early Maya Community in Belize, edited by Norman Hammond, pp. 134-158. Cambridge University Press, Cambridge.

Saul, Julie, and Frank Saul

1997 The Preclassic Skeletons from Cuello. In Bones of the Maya: Studies of Ancient Skeletons, edited by Stephen L. Whittington and David M. Reed, pp. 28-50. Smithsonian Institution Press, Washington, DC.

Scherer, Andrew

2017 Bioarchaeology and the Skeletons of the Pre-Columbian Maya. Journal of Archaeological Research 25:133-184. 
Sharpe, Ashley E., George D. Kamenov, Adrian Gilli, David A. Hodell,

Kitty F. Emery, Mark Brenner, and John Krigbaum

2016 Lead $(\mathrm{Pb})$ Isotope Baselines for Studies of Ancient Human Migration and Trade in the Maya Region. PLOS ONE 11:e0164871.

Smith, Bruce N., and Samuel Epstein

1971 Two Categories of ${ }^{13} \mathrm{C} /{ }^{12} \mathrm{C}$ Ratios for Higher Plants. Plant Physiology 47:380-384.

Somerville, Andrew D., Mikael Fauvelle, and Andrew W Froehle

2013 Applying New Approaches to Modeling Diet and Status: Isotopic Evidence for Commoner Resiliency and Elite Variability in the Classic Maya Lowlands. Journal of Archaeological Science 40:1539-1553.

Spence, Michael W., and Christine D. White

2009 Mesoamerican Bioarchaeology: Past and Future. Ancient Mesoamerica 20:233-240.

Storey, Rebecca

2004 Ancestors: Bioarchaeology of the Human Remains of K'axob. In K'axob: Ritual, Work, and Family in an Ancient Maya Village, edited by Patricia A. McAnany, pp. 109-138. Cotsen Institute of Archaeology, University of California, Los Angeles.

Thompson, Lori

2005 A Comparative Analysis of Burial Patterning: The Preclassic Maya Sites of Chiapa de Corzo, Kaminaljuyu, Tikal, and Colha. Unpublished Ph.D. dissertation. Department of Anthropology, University of Texas, Austin.

Tiesler, Vera

2010 "Olmec" Head Shapes Among the Preclassic Period Maya and Cultural Meaning. Latin American Antiquity 21:290-311.

2012 Transformarse en maya: El modelado cefálico entre los mayas prehispánicos y coloniales. Universidad Nacional Autónoma de México/Instituto de Investigaciones Antropológicas, Universidad Autónoma de Yucatán, Mexico City.

2014 The Bioarchaeology of Artificial Cranial Modifications: New Approaches to Head Shaping and Its Meanings in Pre-Columbian Mesoamerica and Beyond. Springer, New York.

Trask, Willa R.

2018 Missionization and Shifting Mobility on the Southeastern Maya-Spanish Frontier: Identifying Immigration to the Maya Site of Tipu, Belize Through the Use of Strontium and Oxygen Isotopes. Unpublished Ph.D. dissertation. Department of Anthropology, Texas A\&M University, College Station. Electronic document, https://oaktrust.library.tamu.edu/handle/1969.1/174168, accessed October 12, 2021.

Tykot, Robert H.

2002 Contribution of Stable Isotope Analysis to Understanding Dietary Variation Among the Maya. In Archaeological Chemistry: Materials, Methods, and Meaning, edited by Kathryn A. Jakes, pp. 214-230. ACS Symposium Series 831. American Chemical Society, Washington, DC

Tykot, Robert, Nikolaas van der Merwe, and Norman Hammond

1996 Stable Isotope Analysis of Bone Collagen, Bone Apatite, and Tooth Enamel in the Reconstruction of Human Diet: A Case Study from Cuello, Belize. In Archaeological Chemistry: Organic, Inorganic, and Biochemical Analysis, edited by M.V. Orna, pp. 355-365. ACS Symposium Series 625. American Chemical Society, Washington, DC.

van der Merwe, Nikolaas J.

1982 Carbon Isotopes, Photosynthesis, and Archaeology. American Scientist 70:596-606.

van der Merwe, Nikolaas, Robert Tykot, Norman Hammond, and Kim Oakberg

2002 Diet and Animal Husbandry of the Preclassic Maya at Cuello, Belize: Isotopic and Zooarchaeological Evidence. In Biogeochemical Approaches to Paleodietary Analysis, edited by Stanley Ambrose and
M. Anne. Katzenberg, pp. 23-38. Advances in Archaeological and Museum Science 5. Springer, Boston.

Verdugo, C., K. Kassadjikova, E. Washburn, K.M. Harkins, and L.

Fehren-Schmitz

2017 Ancient DNA Clarifies Osteological Analyses of Commingled Remains from Midnight Terror Cave, Belize. International Journal of Osteoarchaeology 27:495-499.

Verdugo, Cristina, Kimberly Zhu, Kalina Kassadjikova, Lara Berg, Jannine Forst, Alison Galloway, James E. Brady, and Lars Fehren-Schmitz

2020a An Investigation of Ancient Maya Intentional Dental

Modification Practices at Midnight Terror Cave Using

Anthroposcopic and Paleogenomic Methods. Journal of Archaeological Science 115:105096.

Verdugo, Cristina, Kimberly Zhu, Michael Prout, Nasreen

Broomandkhoshbacht, Alison Galloway, Lars Fehren-Schmitz, and James E. Brady

2020b Implications of Age and Sex Determinations of Ancient Maya Sacrificial Victims at Midnight Terror Cave. International Journal of Osteoarchaeology 30:458-468.

Walker, Phillip L., Rhonda R. Bathurst, Rebecca Richman, Thor Gjerdrum, and Valerie A. Andrushko

2009 The Causes of Porotic Hyperostosis and Cribra Orbitalia: A Reappraisal of the Iron-Deficiency-Anemia Hypothesis. American Journal of Physical Anthropology 139:109-125.

White, Christine D.

2005 Gendered Food Behaviour Among the Maya: Time, Place, Status and Ritual. Journal of Social Archaeology 5:356-382.

White, Christine, David Pendergast, Fred Longstaffe, and Kimberly Law

2001 Social Complexity and Food Systems at Altun Ha, Belize: The Isotopic Evidence. Latin American Antiquity 12:371-393.

White, Christine, Jay Maxwell, Alexis Dolphin, Jocelyn Williams, and Fred Longstaffe

2006 Pathoecology and Paleodiet in Postclassic/Historic Maya from Northern Coastal Belize. Memórias do Instituto Oswaldo Cruz 101(II):35-42.

Wright, Lori E.

2006 Diet, Health and Status Among the Pasionn Maya. A Reappraisal of the Collapse. Vanderbilt University Press, Nashville.

Wright, Lori E., and Christine D. White

1996 Human Biology in the Classic Maya Collapse: Evidence from Paleopathology and Paleodiet. Journal of World Prehistory 10:147-198.

Wright, Lori E., and Francisco Chew

1998 Porotic Hyperostosis and Paleoepidemiology: A Forensic Perspective on Anemia Among the Ancient Maya. American Anthropologist 100:924-939.

Wright, Lori, Juan Antonio Valdés, James H. Burton, T. Douglas Price, and Henry P. Schwarcz

2010 The Children of Kaminaljuyu: Isotopic Insight into Diet and Long Distance Interaction in Mesoamerica. Journal of Anthropological Archaeology 29:155-178.

Wrobel, Gabriel, Carolyn Freiwald, Amy Michael, Christophe Helmke,

Jaime Awe, Douglas Kennett, Sherry Gibbs, Josalyn Ferguson, and Cameron Griffith

2017a Social Identity and Geographic Origin of Maya Burials at Actun Uayazba Kab, Roaring Creek Valley, Belize. Journal of Anthropological Archaeology 45:98-114.

Wrobel, Gabriel D., Julie A. Hoggarth, and Aubree Marshall

2021 Before the Maya: A Review of Paleoindian and Archaic Human Skeletons Found in the Maya Region. Ancient Mesoamerica 32:475-485.

Wrobel, Gabriel D., Shawn Morton, Amy R. Michael, Jack Biggs, and Christopher Andres

2017b The Current State of Research on Ancient Maya Rockshelter Use in Central Belize. Research Reports in Belizean Archaeology 14:311-320. 